\title{
Research on the Integration and Development of Culture Industry and Tourism Industry of Fisherman Village in Rizhao
}

\author{
Zhiyu Qin \\ Rizhao Polytechnic, Rizhao, China \\ Email: 498624233@qq.com
}

How to cite this paper: Qin, Z.Y. (2018) Research on the Integration and Development of Culture Industry and Tourism Industry of Fisherman Village in Rizhao. Open Journal of Social Sciences, 6, 167-175. https://doi.org/10.4236/jss.2018.611012

Received: October 24, 2018

Accepted: November 13, 2018

Published: November 16, 2018

Copyright $\odot 2018$ by author and Scientific Research Publishing Inc. This work is licensed under the Creative Commons Attribution International License (CC BY 4.0).

http://creativecommons.org/licenses/by/4.0/

\section{(c) (i) Open Access}

\begin{abstract}
During the process of revitalizing the rural economy, rural tourism shows a vigorous development momentum, and the integration development of cultural industry and tourism industry is the sustainable way to realize the development of rural tourism economy. This paper first analyzes the motive force of the integration of cultural industry and tourism industry, and then on the basis of analyzing the particularity of the integration and development of cultural industry and tourism industry in rural areas, combined with the development cases of cultural tourism projects in rural areas all over the country, this paper summarizes five integration and development models. As the country's largest folk tourism reception base-Rizhao City, its development status is representative, finally taking Fisherman Folk Tourism Village of Rizhao City as an example, the integration and development path of Fisherman village culture industry and tourism industry in Rizhao City is studied. At the basic level, it is necessary to mine cultural tourism resources. At the driving level, it is necessary to introduce social capital to use the original ecological development model to build a fisherman's village. At the communication level, it is necessary to cultivate a cultural tourism consumer market, and government policy support is needed at the security level.
\end{abstract}

\section{Keywords}

Rural Area, Cultural Industry, Tourism Industry, Integration and Development

\section{Introduction}

Culture and tourism are naturally coupled. As two "sunrise industries" in the 
21st century, cultural industry and tourism industry will inevitably move towards the road of interaction and integration. In rural areas, the cultural industry takes tourism as the carrier, the tourism industry takes the culture as the foundation, and the sustainable development of the two can be realized only by penetrating and crossing each other.

\section{An Analysis of the Integration Power of Cultural Industry and Tourism Industry}

First, meeting the high-level needs of modern tourists is the fundamental driving force for the integration of the two.

According to Maslow's hierarchy of needs, with the improvement of people's living standards, people are no longer satisfied with sightseeing, but want to "increase knowledge" and enrich "experience life" in the process of tourism. The product, which combines the "creativity" of cultural industry and the "intuition" of tourism industry, can meet the needs of consumers. The integration of culture and tourism industry not only enables tourists to enjoy the natural scenery of tourist attractions in tourism consumption, but also to get cultural enjoyment, with tourism activities with local cultural characteristics, tourists can get better satisfaction from the consumption of tourism products [1].

Second, the pursuit of interest by two industries is the internal motive force of the integration of the two industries.

The instinct of the enterprise is to pursue the maximum benefit. It is the highest pursuit of the enterprise to explore how to better meet the needs of the consumer in order to realize the profit maximization and to maintain the long-term competitive advantage. Cultural industry can perfect the structure of cultural industry chain and realize the profit increment of cultural enterprises by integrated with tourism industry. While tourism industry can realize the optimal allocation of resources and improve the market competitiveness of tourism industry and cultural industry by merging with cultural industry. Cultural tourism products with dual effects of culture and tourism can bring huge economic benefits to the two industries. Therefore, the inherent requirement of the integration of culture and tourism industry is the common pursuit of both sides' interests.

Third, policy support and technological innovation are the external driving force for the integration of the two.

American scholar Stiegler believes that the economic regulation of governments is the root of different industrial barriers. Deregulation means the reduction of barriers between industries, so that only when industries intersect with each other, can infiltration and integration be realized. Through the influence of macro guidance, local management and industry policy, the government formulates the development strategy and plans, to guide and support the integration of the two industries. In the process of integration and development of the two, the development of science and technology makes the boundary between industries become smaller and smaller, and the progress of technology fills up the boundaries between industries. The integration of culture and tourism industry is the 
result of the application of technology between the two industries [2].

\section{Particularity of the Integration and Development of Cultural Industry and Tourism Industry in Rural Areas}

Rural tourism is a tourist attraction to rural natural scenery, cultural relics, folk customs, agricultural production, farmers' life and rural environment, and takes urban residents as the target market to satisfy tourists' leisure, vacation, experience, sightseeing and entertainment and other needs. Compared with other tourism forms, village tourism has stronger experience characteristics. In 1999, Joseph Pine and James Gilmore in Harvard Business Review put forward the advent of the era of experience economy, it was announced that after the product economy and service economy, another new economic form-experience economy will become the mainstream, and the experience economy will begin to be active in the center of the economic stage. According to the best experience criterion put forward by psychologist Mikhail, it is so challenging that a person is so immersed in it so that he forgets the passage of time and does not realize his own existence.

According to this experience criterion, in the process of integrating the two industries, it is necessary to give priority to enhancing tourists' experience at all times. The experience economy in rural areas is the organic combination of tourists' leisure and entertainment, tourism, labor experience, human emotion experience consumption and natural environment, production activities and local social culture.

\section{An Analysis of the Relationship between Cultural Industry and Tourism Industry in Rural Areas}

The integration of cultural industry and tourism industry in rural areas is a complex economic activity. Its relationship is mainly manifested in two aspects. The first is mutual penetration, tourism is the carrier of culture, and the open tourism industry improves and extends the cultural industry chain. Culture is the soul of tourism enriching the connotation and extension of the tourism industry; secondly, the advantages complement each other, the advantages of tourism are in the market, the advantages of culture are connotation, the tourism industry expands the creative vision and market space of the cultural industry, and the cultural industry is tourism. The industry has increased cultural added value and provided greater profit margins [3].

The author summarizes the following five models by consulting the relevant materials at home and abroad and combining with the development cases of cultural tourism projects in rural areas all over the country.

First, the original ecological form.

In a region rich in natural and humanistic resources, to choose a village with convenient transportation and typical contents for construction, taking the natural life production and the natural form of the village as the tourist content, apart from the necessary infrastructure construction, there are no other processing 
changes, allowing tourists to communicate naturally with the local residents in a real environment, and even to participate in the work themselves.

Second, retro reductive form

Select a particular village to restore the disappeared village culture, and let visitors understand the village culture of the past, from the appearance of the village to each yard, to make a restoration and display of traditional material life and festival etiquette. These aspects will attract a large number of domestic and foreign tourists, such as Xidi Hong village in Anhui province.

Third, theme concentrated

In the villages with abundant and unique culture, choose appropriate section to build theme gardens with the theme of local culture, and concentrate on presenting the essence of the local culture, such as the Dongyi Little Town in Rizhao, which falls into this category. Its advantage is that it is convenient for tourists to fully understand the essence of local or national folk culture in a short time, but it is also easy to make the theme park appear commercialization phenomenon, which is not conducive to the sustainable development of theme park.

Fourth, activity representation

The villages which have preserved the folk style and the simple traditional culture have stimulated the transient tourist flow through regular or irregular cultural activities. There are mainly two kinds of situations. One is the fixed national folklore festival activities, such as the "Nadam Fair" in Inner Mongolia, the "Corban Festiva" of the Hui nationality and the "Torch Festival" of the Bai and Yi nationalities, etc, which will attract a large number of tourists during the festival. The other is the unfixed folk cultural performance, for example, folk traditional culture and art team unscheduled exhibition in the village, can attract the surrounding people to enjoy from far away, and furthermore attract tourists to the village tourism.

Fifth, theme attached to the meeting

The theme of folk culture is combined with the tourism facilities with a specific function to Form a complementary effect. For example, the famous Suzhou Gardens has traditionally been opened to the outside world only during the day to allow visitors to appreciate the artistic and cultural connotations of the Jiangnan landscape. It is not open to the public at night, but recently the "Classical Night Garden" activity was launched in the Master of Nets Garden. Each hall in the garden was used to display one or two sections of Suzhou Opera, Kunqu Opera and other kinds of local folk culture and art. Visitors can also experience Suzhou gardens in the night scene of the artistic conception.

The problems existing in the current integration of cultural industries and tourism industries in rural areas are first manifested in the participation of villagers. The industrial integration has brought huge impacts on the production and lifestyle of local residents. Local residents have not really participated in it; Secondly, the countryside is obviously backward in terms of infrastructure and management system. Whether it can break through the "bottleneck" of rural 
tourism development decentralization and inefficiency is the key to industrial integration.

\section{Successful Cases of Cultural Industry and Tourism Industry Integration in Rural Areas}

\section{Case 1: Ancient Village Tourism}

Qingyan Ancient Town is located in the southern suburb of Guiyang City, Guizhou Province. The town has historical relics such as the Qingyan teaching site, the former residence of Mr. Ping Gang, and the Red Army Long March Operation Command. It was announced by the Ministry of Construction and the State Administration of Cultural Heritage. Two batches of famous historical and cultural towns in China.

Generally speaking, "ancient village town" refers to an ancient village ancient town that was formed in a certain historical period and has certain historical significance, cultural characteristics and artistic value. Ancient Village is an organic whole of local economy, culture, life and customs. It not only has tangible tourism resources such as ancient buildings, historical blocks and folk crafts, but also intangible tourism resources including ethnic art, space environment and festival activities [4].

Case 2: The birthplace of "Yimeng Mountain Minor"

Baishiwu is located in the south of Mengshan Mountain. During the War of Resistance Against Japanese Aggression, this area was once the place where the leading organs and logistics organs of the Shandong Party and Government Army were regularly active and stationed. The anti-Big one school and the "Popular Daily" printing office have been stationed here for a long time, and the site still exists.

Red tourism is a new bud of tourism. Driven by national policy guidance, promotion and market demand, red tourism has flourished in recent years. Red tourism refers to the revolutionary memorial and memorial as an external form. With its revolutionary history, revolutionary deeds and revolutionary spirit as its connotation, it organizes and receives tourists to visit and learn to achieve the revolutionary spirit and accept the revolutionary tradition education. And tourism activities that reinvigorate, relax, and increase the purpose of experience.

\section{Integration and Development Path of Fisherman Village Culture Industry and Tourism Industry in Rizhao City}

At present, the reception range of the Fisherman Household Tourism is from two cities in the north of Rizhao City to the Lanshan District in the south. The coastal sightseeing line is more than 64 kilometers long. In the north, the National Seaside Forest Park is the core scenic spot, and in the middle is taking the Wangjiazhai Village, which is close to the third bathing place, fishing villages such as Qiaojiadun, Qiantanxi and Houtanxi are the main bodies. Now there are 30 folk tourism villages with more than 80,000 beds, which has become the larg- 
est folklore tourist reception base in the country. The scale effect of this kind of village fishermen household has been formed, the free flow and free competition of elements can be realized between neighboring villages.

However, with the development of folklore tourism, first of all, in the aspect of village appearance, some fishermen adopted the construction mode of city guesthouses in order to expand their business space, to abandon the traditional residential forms with rich characteristics, and greatly reduced the absorbability of tourists, and the continuity of the traditional style was also cut off; the second service was too monotonous and was limited to providing accommodation or catering, neglecting the excavation of cultural values such as local and folk customs, etc. As a result, Rizhao Fisherman Household Tourism has no original and high level of cultural tourism consumption, and there is no resounding rural leisure tourism brand, which affects the sustainable development of Fisherman Village.

\subsection{Basic Level-Mining Cultural Tourism Resources}

First, dig into the cultural connotation of Fisherman village tourism resources and enhance the integration depth. Tourism resources are the core part of the development of tourism industry as well as an important part of cultural industry. The traditional marine culture of Fisherman villages in Rizhao has its unique characteristics and connotations. The ancients believed that Rizhao was the place where "sunrise at sea, dawn first", the cradle of Dongyi national civilization and the source of Chinese solar culture. The solar culture of Rizhao has a great influence on the whole world and is unique, and is an important research content of Rizhao's traditional marine culture. As the origination of Dongyi culture, Rizhao is also the earliest place of origin of fishery salt culture. The town of Tao Luo is located along the coast, with rich salt resources and a long history of salt making, where had salt fields and salt officials in ancient times. The long history of salt making has formed a unique salt culture of Rizhao; and accompanied by the sea, the work way of living off the sea has deeply influenced the concept of life and psychological characteristics of the fisherman villages, which formed a unique folk culture of fishermen, includes fishing folklore, the folklore of fishing operations, as well as the daily life of fishermen, such as belief, etiquette, diet, clothing, festivals, folk songs and dances, and so on. For these traditional marine cultures, to maintain their own original life and customs, and continue to pass on, finally, the formation of brand effect is made to enhance the depth of integration.

Second, integrate marine cultural tourism resources, to build Rizhao "Sea Culture experience Festival" brand. During the peak tourism season, the Rizhao "Sea Culture experience" brand was launched, which focuses on the three modules of solar culture, salt culture and folk culture. The solar culture experience module allows tourists to experience traditional solar sacrificial dance, and how to turn the newly harvested wheat into sun-shaped cakes; salt culture modules 
that let visitors understand the history of salt making in Rizhao and experience the salt making process; and in folk culture modules, they can participate in the sacrificial offerings to sea, the rabn, to the goddess of the sea and other fishermen sacrificial activities, field teaching how to make black pottery and farmers painting embroidery, to enrich the tourist experience.

\subsection{Driving Stratification-Introducing Social Capital to Construct Yujia Village by Using Original Ecological Development Mode}

The government transferred to the enterprise by way of franchise, and the government and the enterprise established a community relationship of "Benefit sharing, risk sharing, whole process cooperation" to build and develop the fisherman village together. In the process of construction, while ensuring the maximum utilization of coastal first-line high-quality resources and exerting the agglomeration effect of related functions such as tourism, we should pay attention to protecting the original ecology of the villages, and create a special space different from that of the general urban areas. Advocating the local renovation and upgrading of residential buildings, preserving and maintaining the local traditional style, giving priority to small businesses such as lodging and boutique hotels in tourism, and merging with aboriginal living areas in order to preserve the original ecological base. There can be no obvious functional zoning, the internal traffic should be mainly functional roads, aiming at strengthening the links between the districts.

At the micro level, materials such as stone, wood and reed are used to transform and build residential accommodation, hotels and other functional buildings, so as to integrate contemporary construction with traditional construction methods in form; and pay attention to the maintenance and renewal of traditional architectural features in terms of style and appearance, the combination of the traditional structure restoration and the new structure application in the structure. At the same time, the traditional culture, such as solar culture, salt culture and Fisherman folk custom culture, are embodied in the building characteristics to realize the matching between the space experience and the cultural background [5].

\subsection{Communication Level-the Consumption Market of Cultural Tourism}

The integration of communication channels can effectively promote the integration of the market, especially in the context of the information age, network technology and digital technology can vigorously promote the integration of tourism market and cultural market. Tourism products with special features have been disseminated to all parts of the world through channels of cultural propaganda such as radio, television and the Internet. By using multimedia technology, tourism products are displayed in a three-dimensional, comprehensive, visual and vivid manner in front of consumers. Tourism network, tourism 
APP and other network platforms have become an important channel for the public to buy tourism products.

First of all, on the basis of integrating the tourism resources of Fisherman villages, the project of high-quality Fisherman Household Tourism is created, and the competent department of tourism information carries out the study and training of the tourism information system for Fisherman Household Tourism folk tourism households, so as to make them fully aware of the importance of tourism information.

Second, in the area of intelligent tourism marketing, the use of social media to promote fisherman villages in Rizhao City, such as publishing routes and village introductions through tour guides and WeChat friends circles, is more intuitive than paper leaflets, and through the tourist Weibo, WeChat and other We-Media to cultivate the potential consumer market. Working with search engine companies such as Baidu, CTRIP and other large-scale online travel service providers to use external data for data analysis and mining, to achieve precision marketing, and to shoot creative micro-movies on scenic spots, or through film and television implantation to strengthen the interaction online and offline [6].

\subsection{Safeguard Level-Government Policy Support}

Government policy support can be carried out from two aspects: hardware construction and software support. In terms of hardware construction, the government should give priority protection to the clear planning arrangements of the road connection, car park expansion, code (port), tourism public toilets, reception facilities construction and so on. In the aspect of software support, strengthen the guidance of the government and enhance the promotion of industrialization. In view of the characteristics of "Fisherman Household Tourism" is the basic business unit of fishermen's families, there needs give full play to the role of the government in guiding policy, first of all, we should work out the "the Integration Development Plan of Culture Industry and Tourism Industry of Rizhao Fisherman Village", on the premise of refining the "The General Plan of Rizhao Tourism", the goal, image and function of the integration and development of the cultural industry and the tourism industry of "Fisherman Household Tourism" are accurately positioned. Secondly, a set of supporting policies to accelerate the development of the integration of the industry is issued to take into account of the long-term development of supporting and expanding the industry. In terms of the financial support for infrastructure, the preference of the policy of encouraging the development of industrial projects, the strength of support for the development of new formats, the protection of resources and environment, and other compensation policies, where clearly embody the government's industrial orientation and make economy by market mechanism. The third is to hold the annual "China Rizhao Fishermen Culture Festival", to create and strengthen the new image of "South Shandong Seashore Folk Custom Tourism Resort" under the brand "Sunshine Coast". 


\section{Conflicts of Interest}

The author declares no conflicts of interest regarding the publication of this paper.

\section{References}

[1] Huang, L. (2016) Theory and Empirical Analysis of Tourism Industry and Cultural Industry. Development Strategy, 5, 75.

[2] Li, H. (2016) Research on the Integration and Development of Culture and Tourism Industry in Hainan Province. Co-Operative Economy \& Science, 11, 24-25.

[3] Zhang, W.H. (2016) Analysis on the Integration and Development of Tourism Industry and Cultural Industry. Journal of Huanghe University of Science and Technology, 18, 28.

[4] Sun, X.L., et al. (2011) A Comparative Study of Tourism Development Models in Ancient Villages and Towns. Journal of Wuhan Polytechnic, 10, 88-89.

[5] Ding, C.M., et al. (2017) Discussion on the Renewal and Transformation of Rizhao Shanhaitian Folk Tourism Village under the Concept of "Micro-Renewal". Planners, 10, 160 .

[6] Tian, Z.F., et al. (2016) Research on the Integration of Cultural Industry and Tourism Industry under the Background of Internet. Journal of Inner Mongolia University of Finance and Economics, 14, 46. 